\title{
PEMBERDAYAAN ORANG TUA SISWA TK ANNUR KABUPATEN CIREBON MELALUI KETERAMPILAN RAJUT TANGAN DAN ACCESS MARKET.
}

\author{
Dina Pratiwi Dwi Santi ${ }^{\text {1), }}$, Setiyani ${ }^{2)}$, Sri Asnawati ${ }^{3)}$ \\ ${ }^{1,2,3)}$ Pendidikan Guru Sekolah Dasar, FKIP, Universitas Swadaya Gunung Jati Cirebon, \\ 1) e-mail : dinapratiwids@ fkip-unswagati.ac.id, ${ }^{2)}$ e-mail : setiyani_0401509081@yahoo.com, \\ 3) e-mail : sriasnawati88@gmail.com
}

\begin{abstract}
Abstrak
Hampir sebagian besar orang tua siswa berada di sekolah untuk menemani anaknya belajar. Aktivitas mereka yang monoton, seperti mengantar dan menunggu anaknya belajar di TK, sungguh sesuatu yang perlu dipikirkan. Apalagi keberadaan mereka yang bergerombol dan tidak teratur, hanya diisi dengan mengobrol, jajan camilan, atau sesekali arisan kecil untuk menutup kebosanan. Kondisi ini, dapat diupayakan agar aktivitas menunggu itu bisa lebih bermanfaat dan bernilai tambah bagi mereka. Oleh karena itu, tim pengabdi merancang suatu pelatihan dan pendampingan dalam membuat beberapa kreasi yang sebelumnya belum pernah dilakukan. Kreasi tersebut berupa kerajinan rajut tangan yang dibentuk menjadi berbagai macam benda seperti gantungan kunci, konektor masker, bunga, dll. Kerajinan merajut dapat dilakukan kapan saja dan dimana saja. Tujuan kegiatan pengabdian ini untuk meningkatkan (1) aktivitas keterampilan rajut tangan, dan (2) pengetahuan access market orang tua siswa TK B Annur. Metode kegiatan pengabdian masyarakat dilaksanakan dengan ceramah, tanya jawab, dan simulasi. Tahapan yang dilalui diantaranya observasi lapangan, sosialisasi, pra pelatihan, pelatihan, evaluasi dan kegiatan pendampingan. Melalui kegiatan PKM diharapkan orang tua siswa dapat mengembangkan potensinya secara optimal dan menguatkan perekonomian keluarga dengan wirausaha.
\end{abstract}

Kata Kunci : access market, keterampilan, pelatihan, rajut tangan

\begin{abstract}
Most of the students' parents are at school to accompany their children to study. Their monotonous activities, such as escorting and waiting for their children to study in kindergarten, are really something to think about. Especially when they are clustered and disorganized, only filled with chatting, snacking, or the occasional small social gathering to cover boredom. In this condition, efforts can be made so that the waiting activity can be more useful and have added value for them. Therefore, the service team designed a training and mentoring in making several creations that had never been done before. These creations are in the form of hand-knit crafts that are formed into various kinds of objects such as key chains, mask connectors, flowers, etc. Knitting crafts can be done anytime and anywhere. The purpose of this service activity is to improve (1) hand knitting skills activities, and (2) knowledge of access market parents of Kindergarten B Annur students. Methods of service community activities is carried out by lecturing, question and answer, and simulation. The stages taken included field observations, socialization, pre-training, training, evaluation and mentoring activities. Through community service activities, it is hoped that students' parents can develop their potential optimally and strengthen the family economy with entrepreneurship.
\end{abstract}

Keywords : access market, skill, training, hand knitting

\section{PENDAHULUAN}

Sekolah bukanlah semata-mata lembaga pendidikan tempat siswa menimba ilmu, namun lebih luas daripada itu. Seharusnya, sekolah dapat memberikan makna dalam pembentukan watak sehingga dapat berkembang menjadi siswa yang bukan cerdas secara 
kognitif namun sikap dan psikomotorik. Akibatnya, pendidikan yang didapat bermakna untuk menyejahterakan kehidupan. Menurut Wasitohadi (2012) pendidikan bermakna setidaknya mencakup karakteristik menyejahterakan, berkeadilan, dan menghargai martabat manusia.

Pendidikan dapat dilakukan di rumah, sekolah maupun di lingkungan masyarakat. Proses pemberdayaan di dalam bidang Pendidikan (Termasuk PAUD) tidak bisa melalui pendekatan parsial namun holistik yang meliputi sistem pembelajaran, manajemen kelembagaan pendidikan, sarana dan prasarana serta pemberdayaan Sumber Daya Manusia yang termasuk di dalamnya siswa, wali siswa, masyarakat, dan pengguna lulusan (Heryanto, 2009).

Pelibatan wali siswa di dalam Pendidikan diharapkan tidak hanya dalam bentuk konsep dan wacana saja namun lebih pada praktik di lapangan. Komite sekolah merupakan salah satu wadah kumpulan wali siswa yang berperan penting terhadap kemajuan sekolah. Hal ini sejalan dengan pernyataan Megiati (2016) bahwa komite sekolah merupakan merupakan media bersama bagi orang- orang yang peduli, ikhlas, dan tanpa pamrih berjuang untuk kepentingan peningkatan kualitas Pendidikan. Atas dasar untuk pemberdayaan masyarakat, maka digulirkan konsep Komite Sekolah. Oleh karena itu untuk dapat memberdayakan dan meningkatkan peran masyarakat, pihak sekolah harus dapat membina kerja sama dengan orang tua dan masyarakat dengan cara menciptakan suasana kondusif dan menyenangkan bagi siswa dan warga sekolah.

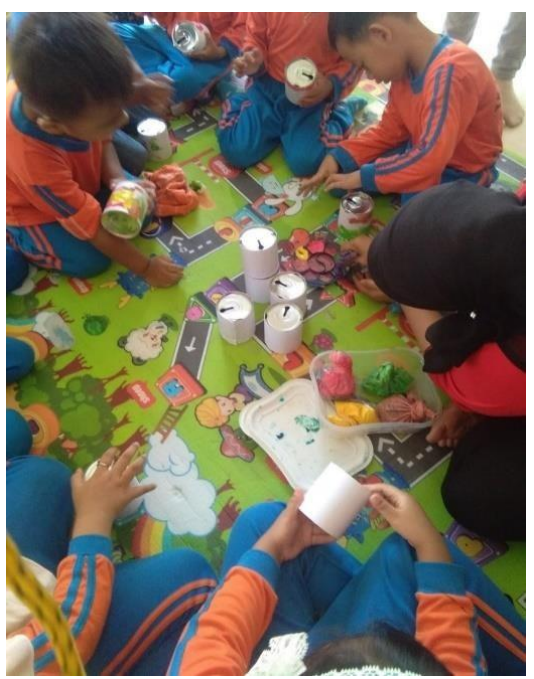

Gambar 1. Aktivitas Belajar Kelas B TK An-Nur
TK ANNUR merupakan TK yang terletak di jalan Mawar Griya Cempaka Arum, Kecamatan Talun, Kabupaten Cirebon. Berdasarkan hasil wawancara tim pengabdi dengan Ibu Fauziyah selaku Kepala Sekolah TK, kegiatan rutin untuk siswa sudah banyak dilakukan. Siswa TK B sudah pernah membuat beberapa karya seperti celengan, aquarium, dan tempat pensil. Adapun bentuk aktivitas mereka dapat terlihat pada Gambar 1.

Kegiatan belajar yang melibatkan wali siswa, siswa, dan guru dalam rangka menghasilkan suatu karya belum pernah dilakukan. Padahal, hampir sebagian besar orang tua siswa berada di sekolah untuk menemani anaknya belajar. Aktivitas yang dilakukan orang tua siswa ketika mengantar dan menunggu siswa di sekolah cenderung monoton, seperti mengobrol, arisan, atau sekedar membeli cemilan. Keberadaan mereka yang bergerombol dan tidak teratur, perlu dipikirkan.

Kondisi ini, dapat diupayakan agar aktivitas menunggu itu dapat bermanfaat dan bernilai tambah bagi mereka. Hal ini dikarenakan orangtua memiliki peran penting dalam membentuk keberhasilan prestasi belajar siswa. Sebagaimana yang dikemukakan oleh Coleman bahwa faktor keluarga seperti kondisi sosiokultural maupun tingkat pendidikan orang tua menjadi penentu berhasil/tidaknya siswa dalam belajar (Wasitohadi, 2012). Oleh karena itu, tim pengabdi merancang suatu pelatihan dan pendampingan untuk meningkatkan aktivitas orangtua siswa TK Annur berupa keterampilan rajut tangan. Pada aktivitas sebelumnya kegiatan ini belum pernah dilakukan. Kerajinan rajut tangan yang dibentuk menjadi berbagai macam benda seperti gantungan kunci, konektor masker, brooche dan bunga.

Menurut KBBI Daring merajut berarti menyirat jaring-jaring. Kegiatan merajut merupakan hasil kerajinan tangan yang dikerjakan secara manual (Vanda, dkk., 2015). Teknik yang digunakan adalah dengan mengaitkan benang dengan hakpen (Rosdiana \& Wijanarko, 2018). Kerajinan merajut dapat dilakukan kapan saja dan dimana saja karena hanya menggunakan peralatan yang sederhana yaitu jarum dan benang (Hanafi dkk, 2020). Oleh karenanya, setiap orang dapat menghasilkan produk kreatif berupa rajut tangan. Produk rajut yang dihasilkan setiap perajin memiliki ciri khas atau keunikan motif masing- masing. Hal ini yang membedakan perajin 
rajut satu dengan yang lain.

Dengan demikian, produk hasil kerajinan rajutan memiliki nilai lebih dibandingkan produk masal hasil industri. Dikarenakan, keistimewaan yang dimilikinya. Sehingga, harga yang ditawarkan pun dapat lebih mahal dibandingkan produk masal hasil industri. Selain itu, diperlukan waktu dalam proses pembuatannya. Sedangkan alat dan bahan yang dapat digunakan untuk menghasilkan produk rajut tangan adalah hakpen, benang nylon, benang wol, gantungan kunci, peniti, lonceng kecil, lem tembak dan pernakpernik lainnya.

Gambar 2 merupakan beberapa contoh produk rajut tangan berupa lonceng dan konektor masker.

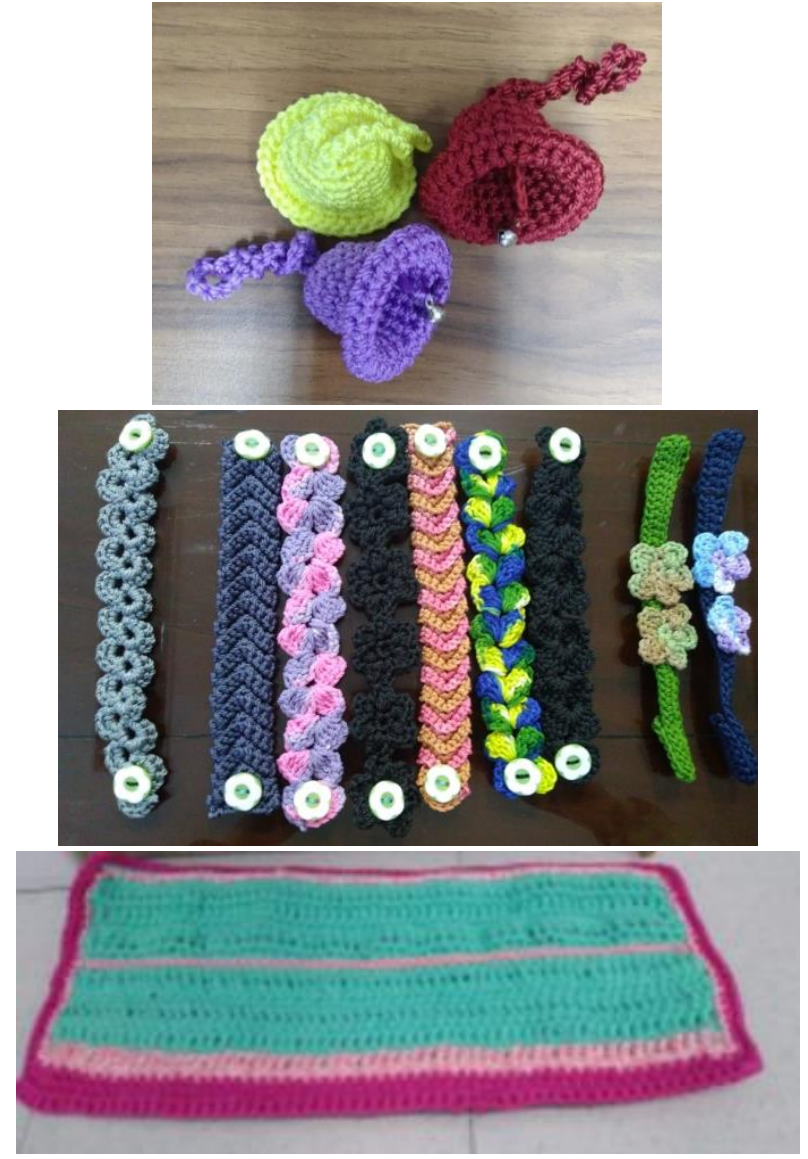

Gambar 2. Contoh Produk Rajut Tangan

Proses yang dilalui untuk menghasilkan produk rajut tangan meliputi memilih desain rajut tangan, pemilihan warna, dan pembuatan produk, selanjutnya dilakukan penjualan/pemasaran. Namun, penjualan/pemasaran dapat juga dilakukan sebelum produk jadi.

Melalui kegiatan pemasaran, pemilik produk akan mengetahui barang yang dibutuhkan oleh konsumen. Agar produk yang dihasilkan memuaskan mereka. Untuk memasarkan produk diperlukan model yang tepat agar sampai kepada konsumen.
Berkaitan dengan pemasaran, penjualan merupakan salah satu kegiatan yang paling penting, karena menjadi sumber pendapatan. Oleh karenanya, beragam strategi digunakan untuk meningkatkan penjualan, salah satunya dengan meluaskan market. Di era teknologi seperti saat ini, banyak tawaran market yang dapat dimanfaatkan untuk menjual produk yang dihasilkan. Salah satunya adalah pemanfaatan media sosial, seperti Instagram, WhatsApp, dan Facebook.

Menurut Safko (Dewi, 2019) bahwa media sosial menjadi alat yang paling efektif untuk melakukan pemasaran maupun penjualan. Sebagaimana peran yang dimiliki media sosial sebagai komunikasi pemasaran yakni upaya penyampaian pesan agar konsumen mengetahui keberadaan produk. Situs internet kaskus mengklaim bahwa jumlah transaksi mencapai Rp. 575 Miliar perbulan, Toko Bagus Rp. 300 Miliar per bulan (Dewi, 2019). Artinya, potensi yang dimiliki transaksi secara online cukup besar.

Berdasarkan pengamatan ditemukan bahwa orangtua siswa TK B Annur sudah memanfaatkan media sosial, namun aktivitas yang dilakukan hanya sebatas sarana untuk komunikasi pribadi. Ada juga yang sudah menerima endorse, hanya jumlahnya tidak lebih dari dua. Mengingat pentingnya pengetahuan tentang access market, maka perlu disosialisakan kepada mereka. Sehingga, dapat memanfaatkan media sosial menjadi lebih berguna. Sehingga, diharapkan orang tua siswa dapat membuka usaha rajut kemudian mendistribusikannya melalui media sosial.

Berdasarkan uraian di atas, maka kegiatan pengabdian kepada masyarakat ini bertujuan untuk meningkatkan :

(1) aktivitas orang tua siswa TK B Annur berupa keterampilan rajut tangan, dan

(2) pengetahuan access market orang tua siswa TK B Annur.

\section{METODOLOGI PENGABDIAN}

Kegiatan PKM dilaksanakan dengan pendekatan pelatihan membuat berbagai hasil rajut tangan yang melibatkan orang tua siswa TK B Annur. Hal ini dilakukan untuk meningkatkan keterampilan rajut tangan bagi orang tua siswa sekaligus mengajarkan bagaimana teknik pemasarannya. Metode pengabdian dilaksanakan dengan menggunakan adalah ceramah, tanya-jawab, dan simulasi (Sumarni, 2020). 
Penerapan metode ceramah untuk memberikan penjelasan tentang teknik merajut dan pemasaran. Para peserta pelatihan mendapatkan kesempatan untuk melakukan tanya-jawab dalam rangka menggali pengetahuan yang tidak mereka ketahui maupun belum dipahami pada saat menerima materi dan pengalaman yang diperoleh ketika melakukan simulasi. Metode simulasi diterapkan dalam rangka untuk meningkatkan keterampilan kerajinan merajut tangan karena mereka dapat mempraktekan materi pelatihan yang diperoleh sebelumnya.

Kegiatan pengabdian kepada masyarakat dilaksanakan melalui beberapa tahapan seperti yang disajikan pada gambar diagram alir sebagai berikut :

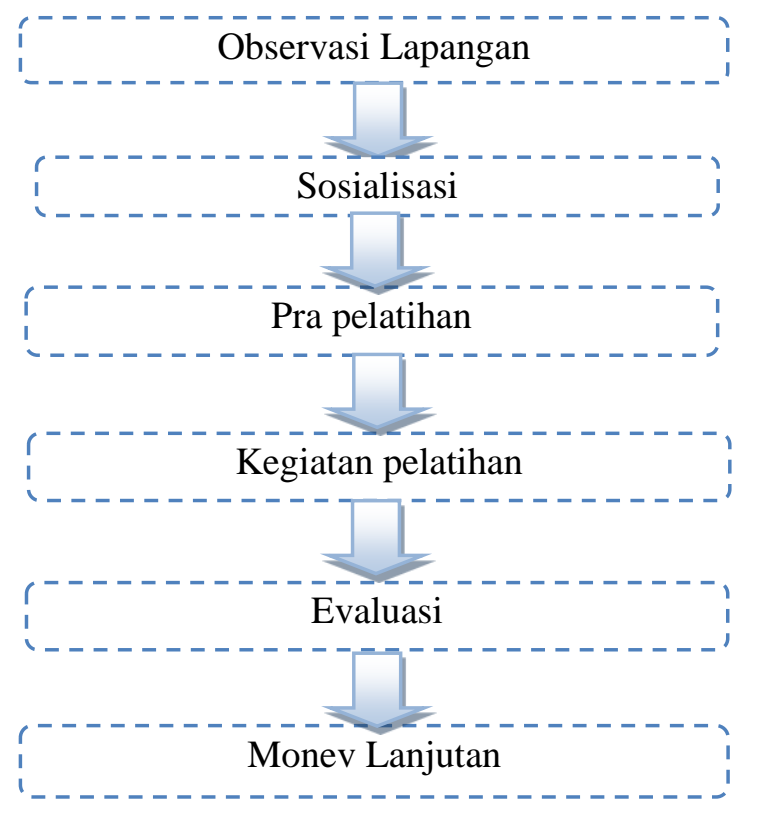

Gambar 3. Tahapan Pengabdian

Berikut penjelasan utuk Gambar 3:

1. Observasi Lapangan

Observasi dilakukan oleh tim PKM untuk mengamati fenomena yang terjadi dan mengidentifikasi masalah melalui pengamatan. Selanjutnya tim melihat kreasi-kreasi yang pernah dilakukan oleh siswa TK B dan mendokumentasikannya.

\section{Sosialisasi}

Kegiatan sosialisasi dilakukan dengan melibatkan kepala sekolah, komite dan Tim PKM. Tujuan kegiatan ini adalah membahas akan diadakan kegiatan PKM menentukan waktu, tempat, serta menentukan orang tua/wali siswa yang bersedia datang ke sekolah untuk mengikuti pelatihan rajut tangan.

\section{Pra Pelatihan}

Kegiatan pra pelatihan dilakukan dengan mempersiapkan alat dan bahan, menyusun alat pengumpul data berupa lembar observasi, angket, dan kelengkapan lainnya. Angket diberikan kepada para peserta dengan tujuan untuk mengetahui tanggapan atau respons peserta terhadap kegiatan yang telah berlangsung. Sedangkan lembar observasi terdiri atas tiga kriteria yakni aktivitas peserta dalam merajut, menyimak paparan pemateri, serta menyimak teknik penjualan, dan digunakan untuk mengetahui aktivitas keterampilan rajut dan market access peserta pengabdian. Alat dan bahan dalam penelitian ini adalah hakpen, benang nylon, wol, gantungan kunci, peniti, lonceng kecil, lem tembak dan pernak-pernik lainnya.

\section{Kegiatan Pelatihan}

Kegiatan pelatihan dibagi menjadi dua sesi yaitu pemaparan materi dan praktik langsung.

5. Evaluasi Pelaksanaan Pelatihan

Evaluasi dilakukan setelah PKM selesai. Tujuan dari evaluasi ini adalah untuk mengetahui tanggapan atau respons peserta terhadap kegiatan yang telah berlangsung.

\section{Monitoring dan Evaluasi (Monev) Lanjutan}

Setelah kegiatan evaluasi pelaksanaan pelatihan rajut tangan, selanjutnya tim pengabdi membentuk wadah untuk berinteraksi dengan peserta melalui WAG (WhatsApp Grup). Tujuan dibentuknya grup whatsapp ini adalah untuk membuat pendampingan selanjutnya dan untuk mestimulus kegiatan merajut dengan memberikan materi-materi dalam bentuk video yang diambil dari youtube.

Adapun keberhasilan dari kegiatan pelatihan rajut tangan dan access market untuk orang tua siswa TK B Annur dapat dilihat dari beberapa indikator yakni kemampuan peserta dalam :

a. Memanfaatkan alat dan bahan untuk merajut, di antaranya mampu memegang hakpen, mengaitkan benang ke hakpen, menggunakan hakpen, dan menghasilkan satu karya handmade/ merajut;

b. Mengikuti instruksi pemateri, di antaranya terlibat penuh dalam kegiatan merajut, dan bekerja sesuai prosedur merajut; serta

c. Memahami teknik penjualan, di antaranya mampu menyebutkan kembali pengertian dan salah satu teknik penjualan, mencontohkan 
bahasa selling, dan menggunakan salah satu media penjualan untuk menari konsumen.

\section{PELAKSANAAN KEGIATAN}

Kegiatan pelatihan keterampilan rajut tangan dan market access bagi orang tua siswa TK B Annur dilaksanakan pada tanggal 27 Agustus 2020 bertempat di halaman sekolah. Kegiatan ini diikuti oleh delapan orang tua siswa dan empat guru. Sedangkan kegiatan pendampingan dilaksanaka satu hari setelah pelaksanaan pelatihan sampai dengan tanggal 16 September 2020. Adapun hal-hal yang ddikerjakan pada kegiatan pendampingan adalah memantau apakah kegiatan merajut berlanjut atau tidak. Selain itu, untuk mestimulus kegiatan merajut diberikan materi-materi dalam bentuk video yang diambil dari youtube.

Tim PKM FKIP Universitas Swadaya Gunung Jati (UGJ) melibatkan dua orang dosen sebagai pemateri serta satu orang dosen sebagai observer dan satu orang mahasiswa sebagai pembantu umum. Berdasarkan tahapan kegiatan yang telah diuraikan pada bagian metode pelatihan, setelah tahap survey, observasi dan pra pelatihan maka tahap selanjutnya adalah peserta mengikuti tahap pelatihan dan pendampingan.

1. Kegiatan Pelatihan

Pada awal kegiatan pelatihan, tim PKM memberikan materi tentang bagaimana teknik merajut. Peserta diperkenalkan dengan alat merajut yaitu hakpen yang dililitkan ke benang nylon. Berikut gambar pemateri pertama memberikan penjelasan tentang macam-macam alat merajut.

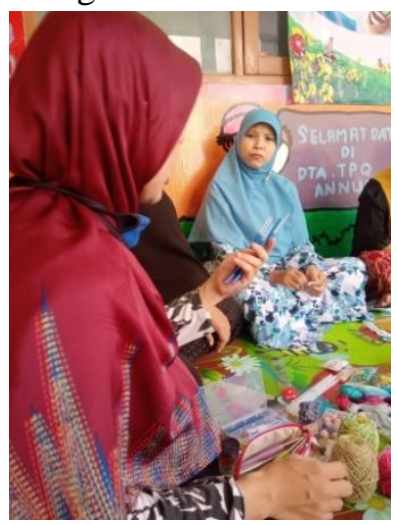

Gambar 4. Pemateri Memberikan Penjelasan MacamMacam Alat Merajut

Selanjutnya pemateri menjelaskan tentang teknik merajut seperti yang tampak pada Gambar 6 .

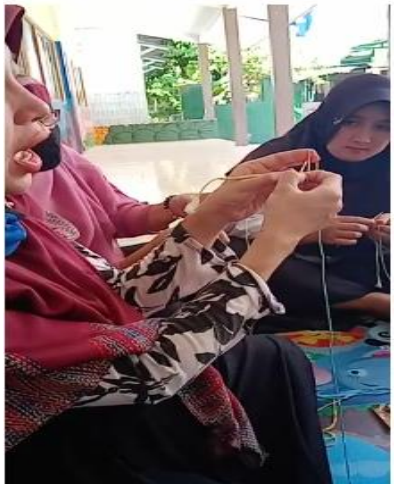

Gambar 6. Pemateri Menjelaskan Teknik Merajut

Beberapa tusuk yang dipraktikan adalah tusuk SC, CH, DC, HDC, SLST . Kegiatan ini dapat dilihat pada Gambar 7.
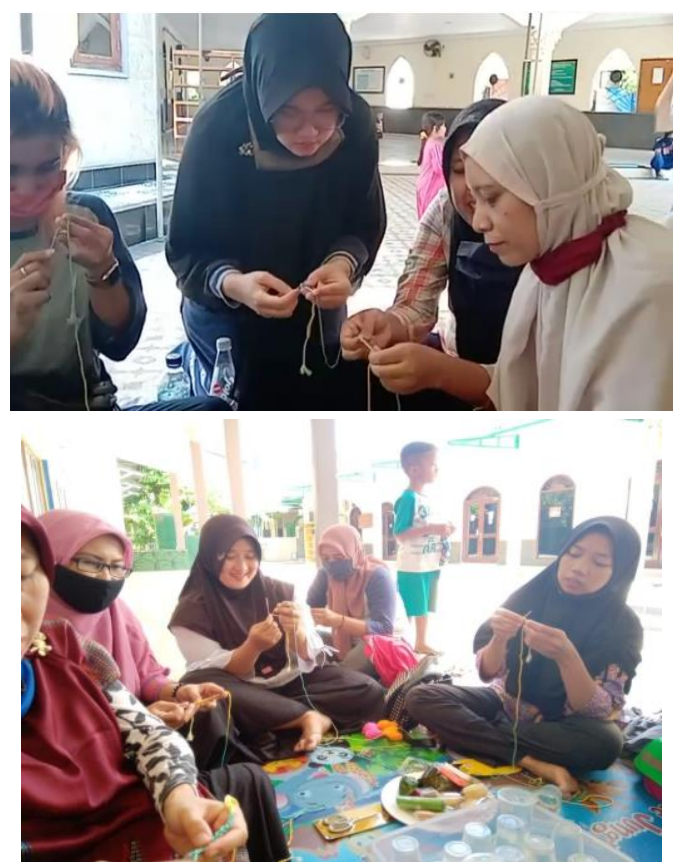

Gambar 7. Aktivitas Merajut Orang Tua Siswa dan Guru Kelas B TK An-Nur

Selanjutnya, peserta membuat sebuah prakarya misalnya gantungan kunci, brooche, dan konektor masker dari rajutan tangan. Adapun beberapa hasil karya peserta dapat dilihat pada Gambar 8 .

Rangkaian kegiatan berikutnya adalah pemberian materi teknik merajut oleh pemateri kedua seperti tampak pada Gambar 9. 

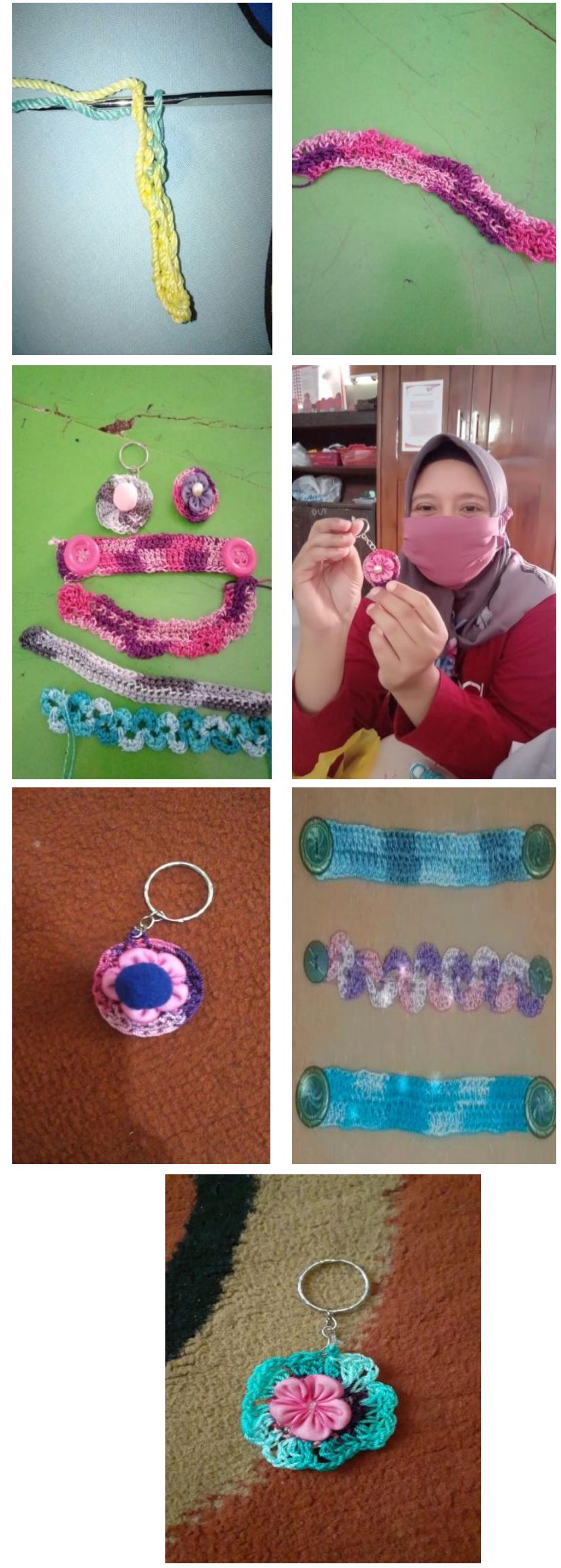

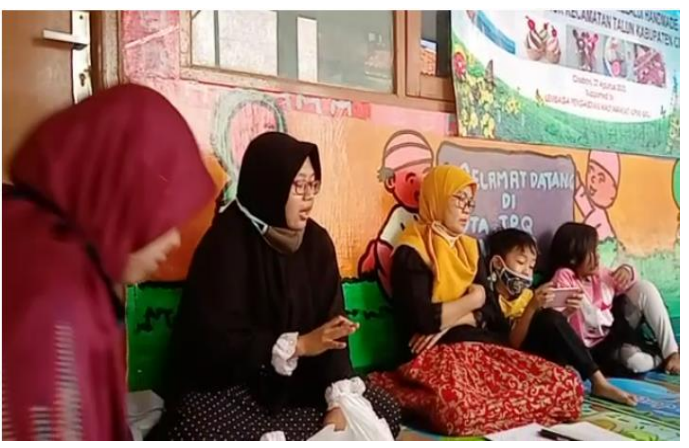

Gambar 9. Pemateri Menjelaskan Tenik Penjualan

Materi yang disampaikan meliputi pengertian teknik promosi dan beberapa teknik promosi di antaranya adalah personal selling dan advertising. Selain penyampaian materi, juga diterapkan tanya jawab kepada peserta untuk mengetahui pemahaman peserta mengenai materi yang disampaikan.

\section{HASIL DAN PEMBAHASAN}

Kegiatan pengabdian yang dilakukan bertujuan untuk meningkatkan aktivitas orangtua siswa TK B Annur dan pengetahuan market access yang dimiliki oleh mereka. Pendekatan yang digunakan adalah pelatihan membuat berbagai hasil rajut tangan yang melibatkan orang tua siswa TK B Annur. Sebagian dari peserta adalah ibu rumah tangga yang kesehariannya beraktivitas, seperti mengantar dan menunggu anaknya sekolah.

Aktivitas yang dilakukan orang tua siswa ketika mengantar dan menunggu siswa di sekolah cenderung monoton, seperti mengobrol, arisan, atau sekedar membeli cemilan. Padahal, aktivitas orangtua siswa yang bermanfaat dan bernilai tambah dapat memberikan kontribusi terhadap keberhasilan belajar siswa. Sebagaimana hasil penelitian yang diperoleh Novianto (2019) yakni sebesar $40,9 \%$ pekerjaan orangtua memiliki kontribusi terhadap hasil belajar siswa. Pekerjaan orangtua yang dimaksud adalah wiraswasta, pedagang, buruh, dan petani. Sejalan dengan hasil penelitian Coleman bahwa faktor keluarga seperti kondisi sosiokultural maupun tingkat pendidikan orang tua menjadi penentu berhasil/tidaknya siswa dalam belajar (Wasitohadi, 2012). Oleh karenanya, untuk meningkatkan aktivitas orangtua siswa TK B Annur agar lebih bermanfaat dan bernilai tambah, maka dilakukan pelatihan Gambar 8. Hasil Karya Rajut Tangan Orang Tua Siswakdang dan Guru Kelas B TK An-Nur

Selama kegiatan PKM rajut tangan ini berlangung, salah seorang dosen mengamati aktivitas peserta dan menuliskan hasil pengamatannya pada lembar lembar 
observasi. Aspek yang diamati terdiri dari aktivitas peserta dalam merajut, aktivitas peserta dalam menyimak paparan pemateri, dan aktivitas peserta dalam menyimak teknik penjualan. Adapun rekapitulasi hasil observasi peserta dapat dilihat pada tabel 1.

Tabel 1. Rekapitulasi Hasil Observasi

\begin{tabular}{|c|c|c|}
\hline Kriteria & Pernyataan & $\begin{array}{c}\text { Terlaksana } \\
(\%)\end{array}$ \\
\hline \multirow{4}{*}{$\begin{array}{l}\text { Aktivitas } \\
\text { Peserta dalam } \\
\text { Merajut }\end{array}$} & $\begin{array}{l}\text { Peserta mampu } \\
\text { memegang hakpen }\end{array}$ & $100 \%$ \\
\hline & $\begin{array}{l}\text { Peserta mampu } \\
\text { mengaitkan benang ke } \\
\text { hakpen }\end{array}$ & $97.2 \%$ \\
\hline & $\begin{array}{l}\text { Peserta mampu } \\
\text { menggunakan hakpen }\end{array}$ & $97.2 \%$ \\
\hline & $\begin{array}{l}\text { Peserta mampu } \\
\text { menghasilkan satu karya } \\
\text { handmade/merajut }\end{array}$ & $75 \%$ \\
\hline \multirow{4}{*}{$\begin{array}{l}\text { Aktivitas } \\
\text { Peserta dalam } \\
\text { Menyimak } \\
\text { Teknik } \\
\text { Penjualan }\end{array}$} & $\begin{array}{l}\text { Peserta mampu } \\
\text { menyebutkan kembali } \\
\text { pengertian teknik } \\
\text { penjualan }\end{array}$ & $80.6 \%$ \\
\hline & $\begin{array}{l}\text { Peserta mampu } \\
\text { menyebutkan Kembali } \\
\text { salah satu teknik } \\
\text { penjualan }\end{array}$ & $80.6 \%$ \\
\hline & $\begin{array}{l}\text { Peserta mampu } \\
\text { mencontohkan bahasa } \\
\text { selling }\end{array}$ & $80.6 \%$ \\
\hline & $\begin{array}{l}\text { Peserta mampu } \\
\text { menggunakan salah satu } \\
\text { media penjualan untuk } \\
\text { menarik konsumen }\end{array}$ & $80.6 \%$ \\
\hline \multirow{2}{*}{$\begin{array}{l}\text { Aktivitas } \\
\text { Peserta } \\
\text { dalam } \\
\text { Menyimak } \\
\text { Paparan } \\
\text { Pemateri }\end{array}$} & $\begin{array}{l}\text { Peserta terlibat penuh } \\
\text { dalam kegiatan } \\
\text { merajut }\end{array}$ & $91.7 \%$ \\
\hline & $\begin{array}{l}\text { Peserta bekerja sesuai } \\
\text { prosedur merajut }\end{array}$ & $94.4 \%$ \\
\hline \multicolumn{2}{|l|}{ RATA-RATA } & $87.8 \%$ \\
\hline
\end{tabular}

Berdasarkan hasil rekapitulasi lembar observasi pada tabel 1, rata-rata aktivitas peserta sebesar $87.8 \%$ termasuk kriteria baik. Seluruh peserta dapat memegang hakpen dan mengaitkannya pada benang dengan baik. Peserta juga aktif terlibat dalam diskusi terkait teknik penjualan suatu produk. Setelah kegiatan PKM ini berlangsung, peserta diminta untuk mengisi angket respons terhadap kegiatan yang telah dilakukan. Angket respons terdiri dari dua pertanyaan terbuka. Tujuan diberikannya angket ini adalah untuk mengevaluasi kegiatan PKM yang telah dilakukan. Adapun salah satu hasil angket peserta dapat dilihat pada Gambar 9.

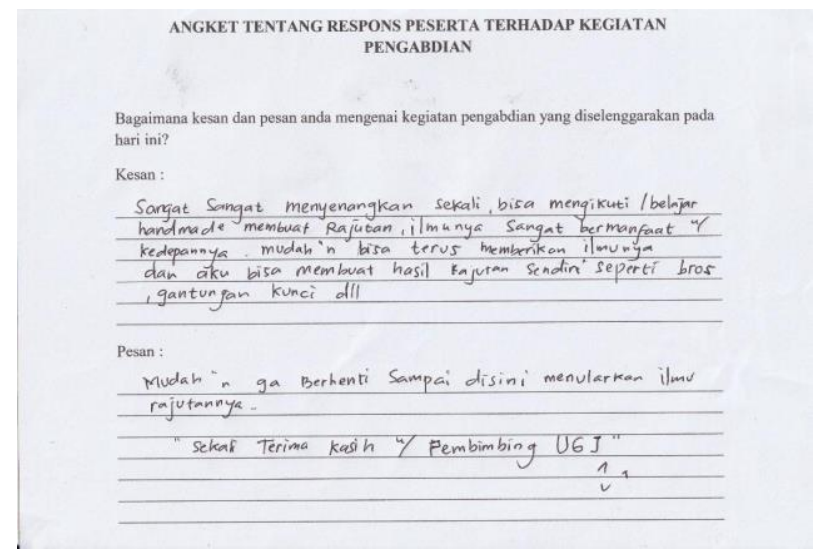

Gambar 9. Salah Satu Angket Respons Peserta

Sebagai luaran tambahan kegiatan PKM Internal UGJ ini, Tim PKM melibatkan media massa yaitu koran kabar Cirebon untuk meliput kegiatan yang telah dilakukan. Adapun berita kegiatan PKM terbit pada harian lokal tanggal 29 Agustus 2020 dan dapat dilihat pada gambar berikut.

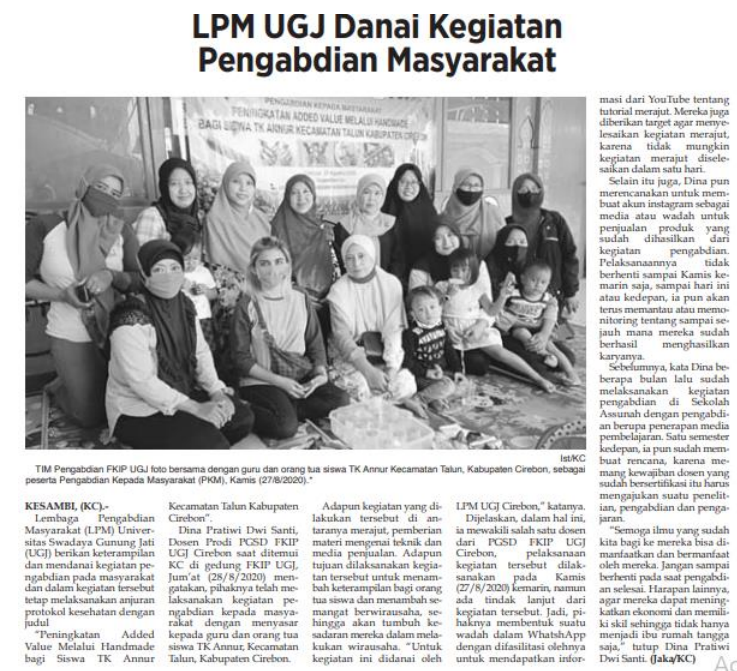

Gambar 10. Berita Kegiatan PKM

Tampak pada Gambar 8 hasil rajutan peserta masih belum rapih karena ini adalah kali pertama peserta belajar merajut. Kegiatan PKM ini menjadi stimulus bagi peserta untuk berlatih lagi agar memperoleh hasil maksimal sehingga layak dipasarkan. Setelah membuat beberapa karya rajut tangan, peserta dibekali materi bagaimana memasarkannya.

Metode sederhana yang digunakan adalah melalui media sosial. Menurut Safko (Dewi, 2019) bahwa media sosial menjadi alat yang paling efektif untuk melakukan pemasaran maupun penjualan. Sebagaimana peran yang dimiliki media sosial sebagai komunikasi pemasaran yakni upaya penyampaian pesan agar konsumen mengetahui keberadaan produk. Situs internet kaskus mengklaim 
bahwa jumlah transaksi mencapai Rp. 575 Miliar perbulan, Toko Bagus Rp. 300 Miliar per bulan (Dewi, 2019). Artinya, potensi yang dimiliki transaksi secara online cukup besar.

\section{Ucapan Terima Kasih}

Kegiatan ini terselenggara atas dukungan baik secara moriil maupun materiil dari Lembaga Pengabdian kepada Masyarakat (LPM) Universitas Swadaya Gunung Jati (UGJ) Cirebon.

\section{PENUTUP}

\section{Kesimpulan}

Kegiatan PKM bagi orang tua siswa TK B Annur dalam rangka meningkatkan aktivitas berupa keterampilan rajut tangan dan market acces nya berjalan lancar sesuai dengan rencana. Indikator ketercapaian kegiatan ini diantaranya kemampuan peserta dalam merajut, jumlah peserta yang melebihi target, keaktifan peserta dalam berdiskusi tentang proses merajut ataupun market acces nya, terbentuknya kreativitas peserta, kegiatan pembinaan dan pendampingan yang dilakukan oleh tim pengabdian. Kegiatan yang telah dilaksanakan turut andil dalam memberdayakan perempuan khususnya wali siswa TK Annur untuk lebih produktif dan mampu menghasilkan produk ekonomi kreatif.

\section{Saran}

Pengabdian berupa aktivitas merajut dapat dilanjutkan sehingga diperoleh hasil yang layak jual. Selain itu, untuk memberikan manfaat kepada masyarakat lebih luas, maka sasaran kegiatan ini dapat juga diberikan kepada wanita usia yang sudah tidak produktif. Agar mereka memiliki aktivitas sehari-hari yang lebih bermanfaat.

\section{DAFTAR PUSTAKA}

Dewi, R. P. (2019). Sosial Media sebagai Sarana Jual Beli Online.

Hanafi, H., Suryanti, S., \& Hendra, H. (2020). Kerajinan Rajut sebagai Produk Cendramata di Nagari Tuo Pariangan. Jurnal Abdimas Mandiri, 4(1).

Heryanto, N. (2009). Pemberdayaan Masyarakat dalam PAUD Nonformal. Jurnal Pendidikan Luar Sekolah, 4(2).

Megiati, Y. E. (2016). Pemberdayaan Komite
Sekolah: Kajian Konsep dan Implementasinya. SAP (Susunan Artikel Pendidikan), 1(2).

Wasitohadi, W. (2012). Mengembangkan Pendidikan Bermakna di Indonesia dan Implikasi-Implikasinya. Satya Widya, 28(1), 83-92.

Sumarni, Prayitno, A.T., \& Adiastuty. (2020). Pendampingan Penulisan Artikel Ilmiah bagi Guru-Guru SMA Kecamatan Jalaksana Kabupaten Kuningan. Al Khidmat : Jurnal Ilmiah Pengabdian Kepada Masyarakat, 3(1). Vanda, Y., Ratnaningsih, R., \& Cahyono, S. A. (2015). Pemberdayaan Anggota PKK Kelurahan Gentan Sukoharjo. SEMAR (Jurnal Ilmu Pengetahuan, Teknologi, dan Seni bagi Masyarakat), 4(1).

Novianto, W. A. (2019). Hubungan Pekerjaan dan Tingkat Pendidikan Orang Tua dengan Hasil Belajar Siswa Kelas IV SDN Gugus Kenanga Kabupaten Pekalongan (Doctoral dissertation, Universitas Negeri Semarang. 
